\title{
Frictional Resistance Calculations on a Ship using CFD
}

\author{
Dunna Sridhar \\ M E Student \\ Marine Engineering \\ A U C E., Visakhapatnam
}

\author{
T V K Bhanuprakash \\ Professor \\ Dept. of Marine Engineering \\ A U C E., Visakhapatnam
}

\author{
H N Das \\ Scientist 'E" \\ H R Wing \\ N S T L., Visakhapatnam
}

\begin{abstract}
In the present study, we conducted propeller open water test, resistance test, and propeller, ship hull interaction for a ship's resistance and propulsion performance, using computational fluid dynamics techniques, where a K-epsilon, K-omega turbulence viscous models were employed. For convenience of mesh generation, unstructured meshes were used in the propeller region of a ship, where the hull shape is formed of delicate curved surfaces. On the other hand, structured meshes were generated for the remaining part of the hull and its domain, i.e., the region of relatively simple geometry. To facilitate the rotating propeller for propeller a moving reference frame motion type technique was adopted. The computational results were validated by comparing with the existing experimental data. In this work we are interested in predicting the frictional resistance offered to a ship during is motion. To this effect we start off with a consideration of the resistance offered to the bare hull in the absence of the propeller and later extend to the case where the propeller is in-place. The thrust generated by the propeller alone without considering the ship (called open water analysis) is also performed using CFD.

FLUENT 6.0®, was used for CFD analysis and for modeling and meshing the packages used are CATIA - V5® and ICEM-CFD® respectively. The open water analysis of the 4-bladed propeller predicted a thrust of $346 \mathrm{kN}$ at $30 \mathrm{rps}$. The bare hull resistance at $228 \mathrm{kN}$ at $18 \mathrm{~m} / \mathrm{s}$, and resistance with propeller in place at $18 \mathrm{~m} / \mathrm{s}$ was found to be $245 \mathrm{kN}$. The results predicted by the CFD analysis were found to be suitable for the present HSDS and it is believed that the hydrodynamics design of the propeller is acceptable for the problem at hand.
\end{abstract}

\section{Keywords}

Resistance performance, propeller and shiphull interaction; Propeller open water performance; Mesh sequencing and converging study; Computational fluid dynamics.

\section{INTRODUCTION}

Thanks to the great advancement of computer performance recently, computational analysis of ship resistance and propulsion using computational fluid dynamics (CFD) is being widely adopted, and the results are being applied to actual design of ships. In those applications, however, the difficulty in mesh generation is the most serious complication for nonexpert users for utilizing CFD with maximum efficiency. In case of mesh generation around a ship hull require special care and experience, because of the delicate and rapidly changing surfaces. This is true even for a propeller and the complexity gets out of control. Therefore, a hybrid meshing approach using unstructured meshing near the complex geometry and structured meshing in the remaining simple geometry domain was suggested. In the present study, we extended the application further and executed resistance and propeller -ship hull interaction tests using structured meshing, which employs unstructured meshing in the propeller region and structured meshing in the remaining region. For propeller open water and propeller-ship hull interaction, a "moving reference frame" motion type technique were used, The present computational results were investigated through comparison with the experimental data from Naval science and technological laboratory, and ITTC results.

\section{COMPUTATIONAL MODEL AND CONDITION}

A High speed displacement ship was selected as the object ship, and the INSEAN E779A model propeller was selected as the object propeller. The principal particulars are described in Tables 1 and 2. 
Table 1: Principal particulars of INSEAN E779A model propeller

\begin{tabular}{|l|l|}
\hline Propeller diameter & $D_{\mathrm{p}=227.27 \mathrm{~mm}}$ \\
\hline Number of blades & $\mathrm{Z}=4$ \\
\hline Pitch ration (normal) & $\frac{P}{D_{\mathrm{p}}}$ \\
\hline Skew angle at blade tip & $Q_{S}^{\text {tip }}$ \\
\hline Rake(normal) & (positive) \\
\hline $\begin{array}{l}\text { Expanded area ratio } \\
\text { diameter }\end{array}$ & $D_{H}=45.53 \mathrm{~mm}$ \\
\hline $\begin{array}{l}\text { Hub } \\
\text { prop.ref.line) }\end{array}$ & $L_{H=68.30 \mathrm{~mm}}$ \\
\hline \begin{tabular}{l} 
Hub length \\
\hline
\end{tabular} & \\
\hline
\end{tabular}

Table 2: Principal particulars of HSDS

\begin{tabular}{|l|l|}
\hline Ship hull & High speed ship hull \\
\hline Principal Dimensions & $\begin{array}{l}\text { Length b.p } 132.0 \mathrm{~m} \\
\text { Breadth } 15.2 \mathrm{~m} \\
\text { Mean draft } 4 \mathrm{~m}\end{array}$ \\
\hline Domain size & $\begin{array}{l}\text { Rectangular domain of length } \\
660, \text { breadth 76m, depth } \\
\end{array}$ \\
\hline Mesh count & $\begin{array}{l}146172,219477 \text { and } 896412 \\
\text { Hexahedral cells. }\end{array}$ \\
\hline
\end{tabular}

\section{Computational Mesh and Boundary Conditions for Propeller Open Water Test}

The continuum was chosen as fluid and the properties of water were assigned to it. A moving reference frame is assigned to fluid with a rotational velocity (1800rpm). The wall forming the propeller blade and hub were assigned a relative rotational velocity of zero with respect to adjacent cell zone. A uniform velocity $6.22 \mathrm{~m} / \mathrm{s}$ was prescribed at inlet. At outlet outflow boundary condition was set. The far boundary (far field) was taken as inviscid wall and assigned an uniform velocity 6.22 $\mathrm{m} / \mathrm{s}$.

\section{Solver Settings for Propeller}

The FLUENT 6.2.16 code was used to solve the three dimensional viscous incompressible flow. The parallel version of FLUENT simultaneously computes the flow equations using multiple processors. The software can automatically-partitions the grid into sub-domains, to distribute the computational job between available numbers of processors.

Fig: 1(a) Boundary conditions

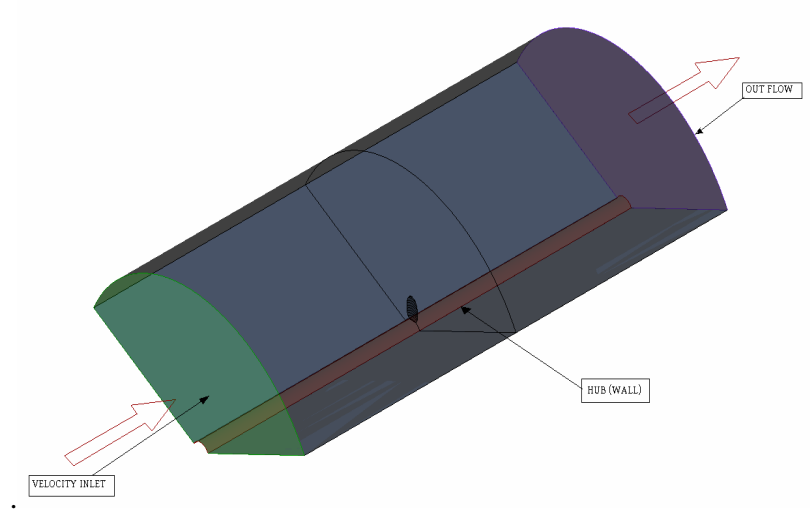

Table 3: Propeller details

\begin{tabular}{|l|l|}
\hline Propeller & THE INSEAN E779A \\
\hline Principal Dimensions & Propeller Diameter=0.227m \\
\hline Domain size & $\begin{array}{l}\text { Cylindrical domain of length } \\
1.75 \mathrm{~m}, \text { dia } 0.97 \mathrm{~m} .\end{array}$ \\
\hline Mesh count & \multicolumn{2}{|}{ 609621 Hexahedral cells. } \\
\hline
\end{tabular}

Table 4: For Propeller flow characteristics

\begin{tabular}{|l|l|}
\hline Pressure Link & SIMPLE \\
\hline Pressure & Standard \\
\hline $\begin{array}{l}\text { Descretisation for } \\
\text { convective fluxes }\end{array}$ & $\begin{array}{l}\text { Quadratic } \\
\text { (QUICK) }\end{array}$ \\
\hline Turbulence model & Standard K-C \\
\hline Near Wall Treatment & Standard wall functions \\
\hline Solver & Steady \\
\hline
\end{tabular}

\section{Computational Mesh and Boundary Conditions for bare hull}

The continuum was chosen as fluid and the properties of water were assigned to it, which is stationary. The wall forming the draft part of the ship hull. Interface and symmetry set as symmetryboundary condition. A uniform velocities

$$
9.73 \mathrm{knots}(5.00512 \mathrm{~m} / \mathrm{s}), \quad 19.46 \mathrm{knots}(10.01 \mathrm{~m} / \mathrm{s}) \text {, }
$$

$31.14 \mathrm{knots}(16.018 \mathrm{~m} / \mathrm{s})$ was prescribed at inlet. At outlet outflow boundary condition was set. The far boundary (far field) was taken as inviscid wall and assigned an uniform velocities $19.46 \mathrm{knots}(10.01 \mathrm{~m} / \mathrm{s}), \quad 31.14 \mathrm{knots}(16.018 \mathrm{~m} / \mathrm{s}) \quad$ The FLUENT 6.2.16 code was used to solve the three dimensional viscous incompressible flow. The parallel version of FLUENT simultaneously computes the flow equations using multiple processors. The software can automatically-partitions the grid into sub-domains, to distribute the computational job between 
available numbers of processors

Fig: 1(b) Boundary conditions for ship hull and its domain

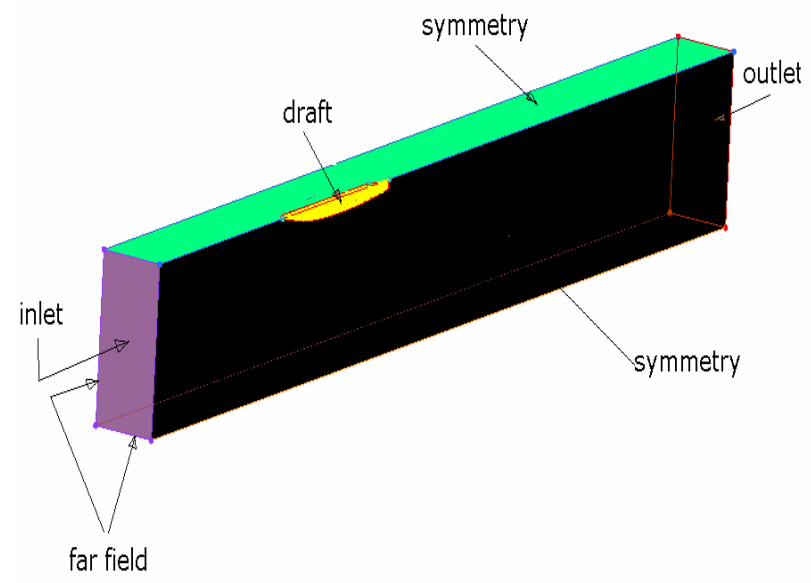

Table 5: Ship hull details

\begin{tabular}{|l|l|}
\hline Ship hull & High speed ship hull \\
\hline $\begin{array}{l}\text { Principal } \\
\text { Dimensions }\end{array}$ & $\begin{array}{l}\text { Length b.p } 132.0 \mathrm{~m} \\
\text { Breadth } 15.2 \mathrm{~m} \\
\text { Mean draft } 4.3 \mathrm{~m}\end{array}$ \\
\hline Domain size & $\begin{array}{l}\text { Rectangular domain of length } 660 \text {, breadth } 76 \mathrm{~m}, \\
\text { depth } 43 \mathrm{~m} .\end{array}$ \\
\hline Mesh count & 146172,219477 and 896412 Hexahedral cells. \\
\hline
\end{tabular}

Table 6: For ship hull flow charecteristics

\begin{tabular}{|l|l|}
\hline Pressure Link & SIMPLE \\
\hline Pressure & Standard \\
\hline $\begin{array}{l}\text { Descretisation scheme for } \\
\text { convective }\end{array}$ & Quadratic Upwind (QUICK) \\
\hline Turbulence model & Standard K- $\omega$ \\
\hline Near Wall Treatment & S S T \\
\hline Solver & Steady \\
\hline
\end{tabular}

\section{Computational Mesh and Boundary Conditions for propeller behind ship hull.}

The FLUENT 6.2.16 code was used to solve the three dimensional viscous incompressible flow. The parallel version of FLUENT simultaneously computes the flow equations using multiple processors. The software can automatically-partitions the grid into sub-domains, to distribute the computational job between available numbers of processors.

Table 7: Propeller behind hullShip hull details

\begin{tabular}{|l|l|}
\hline Propeller & THE INSEAN E779A \\
\hline
\end{tabular}

\begin{tabular}{|l|l|}
\hline Ship hull & High speed ship hull \\
\hline Principal Dimensions & $\begin{array}{l}\text { Length b.p 132.0 m } \\
\text { Breadth } 15.2 \mathrm{~m} \\
\text { Mean draft 4.3m }\end{array}$ \\
\hline Domain size & $\begin{array}{l}\text { Rectangular domain of length 660, } \\
\text { breadth 76m,depth 43m. }\end{array}$ \\
\hline Mesh count & 5472394 Hexahedral cells. \\
\hline
\end{tabular}

Table 8: For Propeller behind flow characteristics

\begin{tabular}{|l|l|}
\hline Pressure Link & SIMPLE \\
\hline Pressure & Standard \\
\hline $\begin{array}{l}\text { Descretisation scheme for } \\
\text { convective fluxes }\end{array}$ & Quadratic \\
\hline Turbulence model & Standard K-€ \\
\hline Near Wall Treatment & Standard wall function \\
\hline Solver & Steady \\
\hline
\end{tabular}

\section{OPEN WATER CHARACTERISTICS OF A PROPELLER}

The performance of propeller is conventionally represented in terms of three non-dimensional coefficients viz., thrust coefficient $\left(\mathrm{K}_{\mathrm{T}}\right)$, torque coefficient $\left(\mathrm{K}_{\mathrm{Q}}\right)$ and the advance coefficient (J). The above mentioned non-dimensional coefficients are defined below using velocity, geometry of the propeller, properties of the fluid in which the propeller is operating and the thrust generated

Table 9: Computational estimation of thrust and torque

\begin{tabular}{|c|c|c|c|c|c|c|c|c|}
\hline $\begin{array}{l}\text { Vel } \\
\text { Ad }\end{array}$ & Rota & Adva & Thrust & Torq & Thrus & Torq & \multicolumn{2}{|c|}{$\begin{array}{l}\text { Exptl } \\
\text { Results }\end{array}$} \\
\hline $\begin{array}{l}\text { Ad } \\
\text { van }\end{array}$ & $\begin{array}{l}\text { tion } \\
\text { al }\end{array}$ & $\begin{array}{l}\text { nce } \\
\text { coeff }\end{array}$ & $\begin{array}{l}\text { force } \\
\mathrm{T}(\mathrm{N})\end{array}$ & $\begin{array}{l}\text { ue } \\
\text { (Q) }\end{array}$ & Coeff & Coeff & $\mathrm{K}_{\mathrm{T}}$ & 10 \\
\hline 6.2 & 150 & 1.092 & 57.908 & 5.725 & 0.034 & 0.152 & 0.0 & 0.16 \\
\hline 6.2 & 180 & 0.910 & 346.05 & 17.84 & 0.144 & 0.327 & 0.1 & 0.3 \\
\hline 6.2 & 240 & 0.682 & 1075.9 & 46.51 & 0.253 & 0.483 & 0.2 & 0.48 \\
\hline 6.2 & 300 & 0.546 & 2102.1 & 87.02 & 0.317 & 0.578 & 0.3 & 0.58 \\
\hline
\end{tabular}

Pressure distribution on the surface of blades is shown in fig. 3 The face and back are experiencing high pressure and low pressure respectively. This explains the development of thrust by propeller at high pressures whereas the propeller is contributing to resistance. It is evident that there is a concentration of high-pressure region near the leading edge of the propeller.

The fig 4 shows the pressure distribution at different radial sections. On the face of the propeller blade section the pressure is increased and being high and close to the leading edge. On the back of the propeller blade section pressure is less and negative in sign. The lift force generated is the result of the differences in pressure on the face and back side of propeller, and for the type of pressure distribution shown in fig.4. It is clear that they reinforce one another and 
that the reduction on the back contributes more to the lift than does the increase on the face.

Fig: 2 Comparison of predicted $\mathrm{K}_{\mathrm{T}} \& \mathrm{~K}_{\mathrm{Q}}$ with experimental data

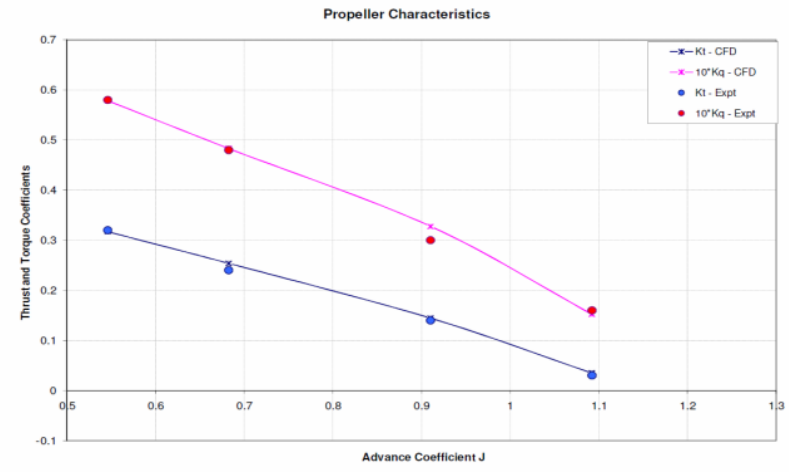

We see that the numerical results compare very well with the experimental results as shown in Table 9. And Fig.2.

Fig: 3 Propeller pressure distribution

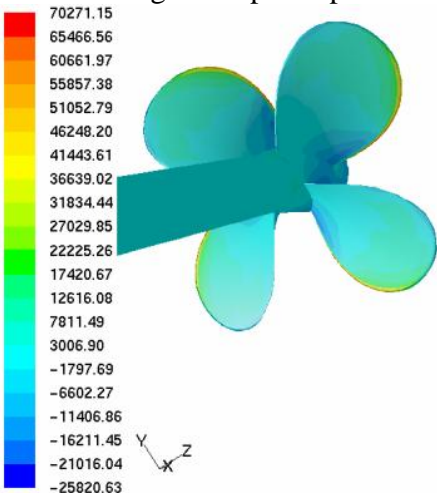

Face of the propeller (picture from open water configuration)

Fig 5 shows that contours of wall $\mathrm{Y}^{+}$are within the range of 26 to 830 . Pathlines around the propeller blades are shown in Fig. 6 This fig tells about how the whirls or wake formed behind the propeller

\section{Computational study of bare hull}

When the propeller is fitted at the stern (the after/rear part of the ship) of a ship, it operates in water that has been disturbed by the ship during its forward motion. The operation of propeller behind the ship hull affects the behavior of the ship. If therefore one wishes to determine the intrinsic performance characteristics of a ship hull, unaffected by the propeller to which it is fitted, it is necessary to make the ship hull operate in undisturbed or "open" water. The performance characteristics of a ship hull usually refer to the variation of its frictional drag (frictional resistance) and frictional coefficient with its speed of advance in open water.

Resistance test The resistance test results are summarized in Table 3, showing comparison of the resistance coefficients with the experimental data from NSTL and the frictional resistance coefficient $(C F)$ was derived from the
ITTC 1957 formula. The overall agreement is very good with close comparison with ITTC results

Fig: 4 Pressure distribution over the radial sections of blade

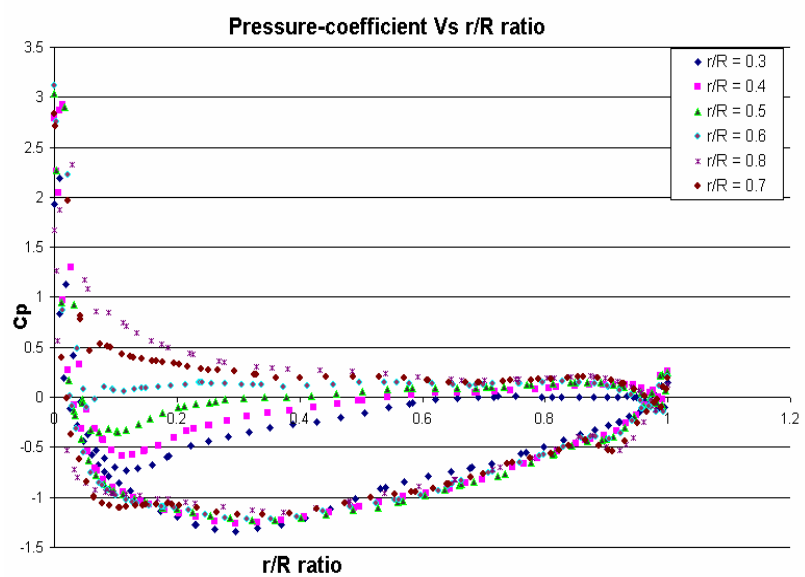

Fig: 5 Contours of wall $\mathrm{Y}^{+}$
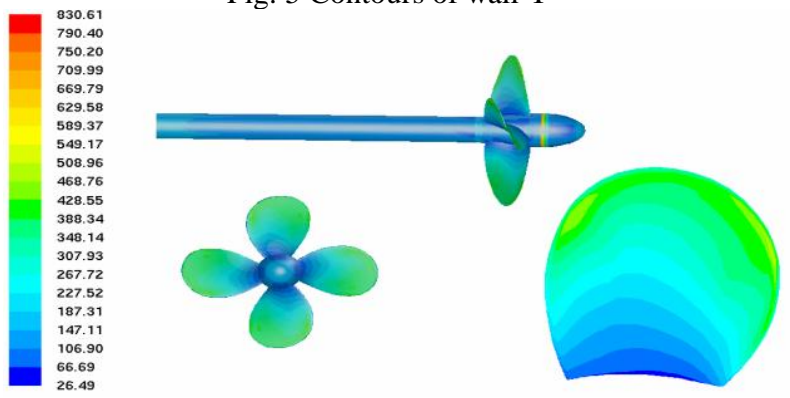

Fig: 6 Path lines around the propeller blades

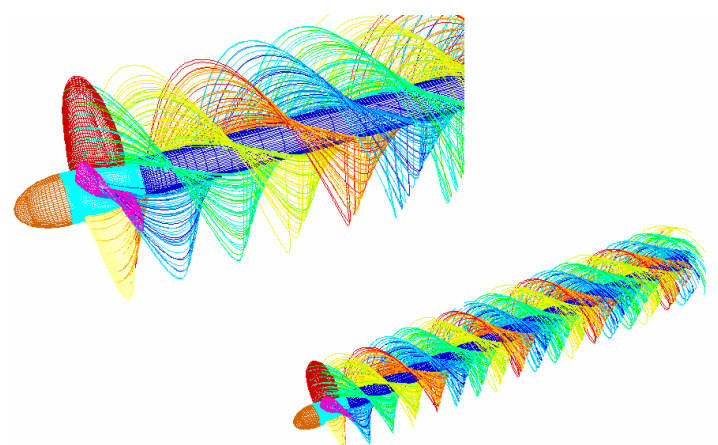

Mesh sequencing and converging study

As mentioned in chapter 4 , we considered a ship of length $132 \mathrm{~m}$, breadth of $15.2 \mathrm{~m}$ and draft $4.3 \mathrm{~m}$. The calculations were performed on 3 grid sizes varying from 146172 hexahedral cells to 896412 hexahedral cells. The frictional resistance and the friction coefficient are obtained from fluent and compared with ITTC (1957). Table 5.3 compares the fluent calculations with ITTC values. We can see that the results are in very good match with the IITC values.

Mesh 1: 146172 hexahedral cells

Mesh 2: 219477 hexahedral cells

Mesh 3: 896412 hexahedral cells 
Table 10 Computational Estimation of Resistance and co-efficient of friction

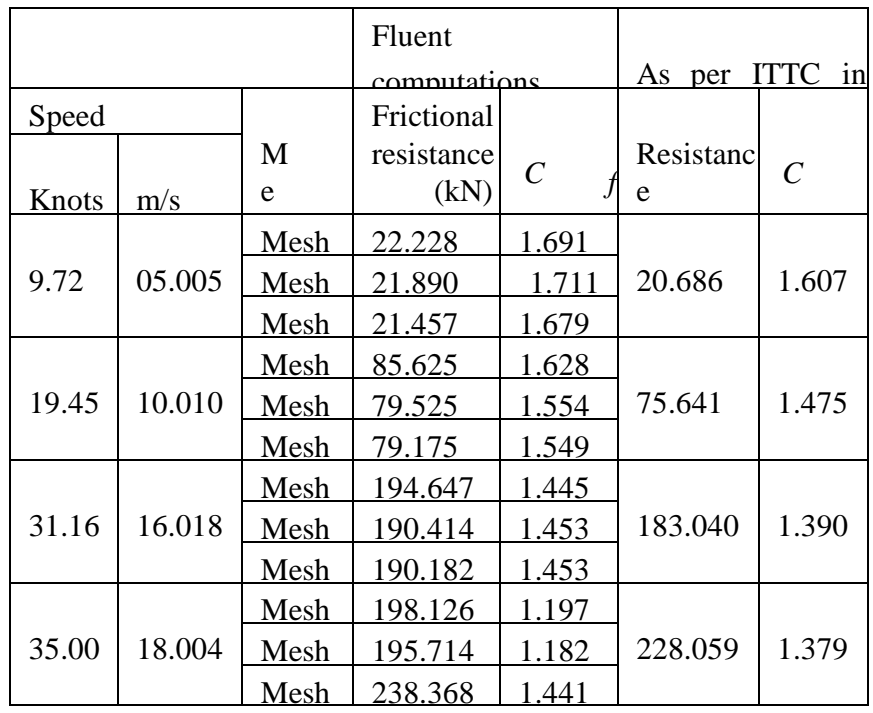

Fig 7: Variation of frictional drag with speed

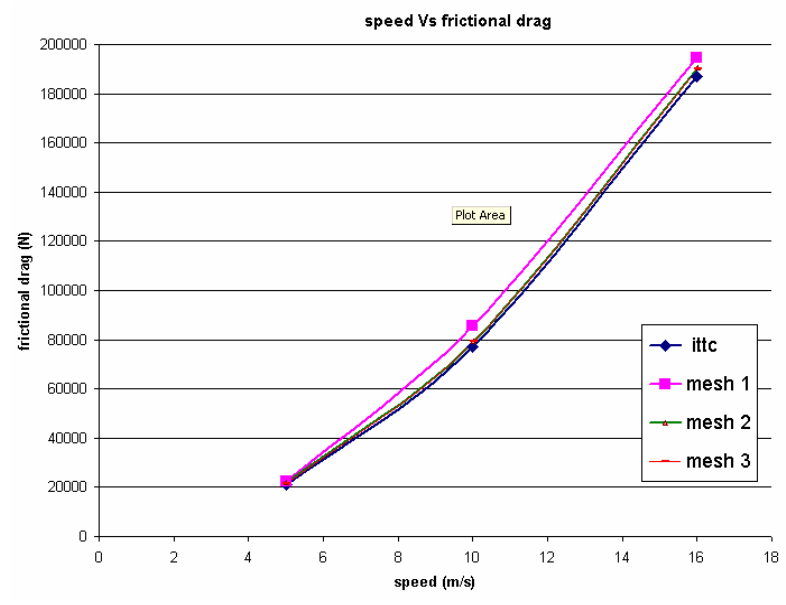

Figure 7 shows variation of Coefficient of friction with speed. Curves obtained from mesh 2 and mesh 3 follows a pattern similar to that of ITTC prediction. These three curves also very close in terms of values. Whereas curve 1 does not match with ITTC prediction and its pattern is also quite different. So, it is understood that the density of mesh in mesh1 was inadequate to capture the flow and other two meshes are adequate. The finer mesh gave better results. The finer mesh amongst these two, i.e., mesh 3 is expected to give best results
Fig 8: Variation of coefficient of frictional drag with speed

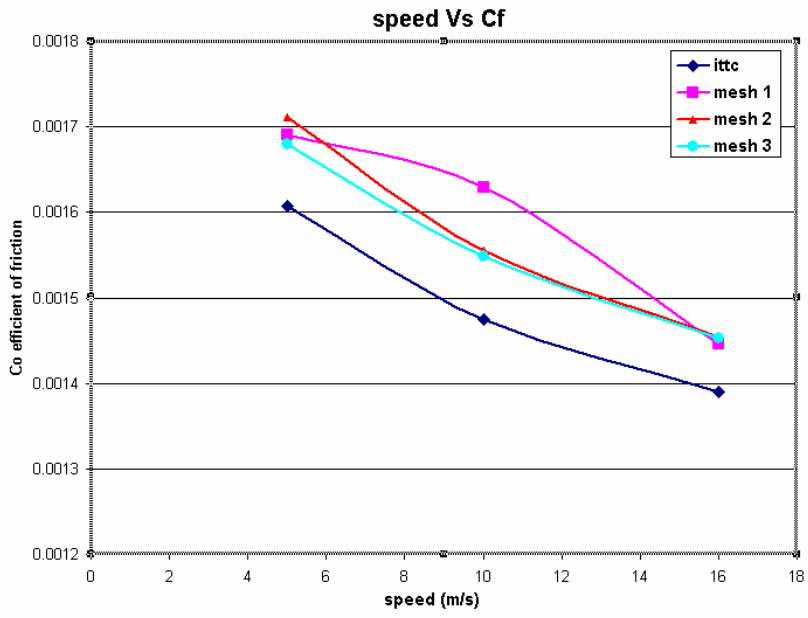

\section{Computational study of propeller behind ship hull}

When a propeller produces thrust it accelerates the water flowing through the propeller disc and reduces the pressure in the flow field ahead of it. The increased velocity of water at the stern of ship and reduced pressure cause an increase in the resistance of the ship. If $\mathrm{R}_{\mathrm{T}}$ is the total resistance of the ship at a given speed in the absence of the propeller and $\vec{R}_{\mathrm{T}}$ is the total resistance at the same speed when the propeller is producing a thrust $\mathrm{T}$, then the increase in resistance due to the action of propeller is:

$$
\begin{aligned}
& \delta R=R_{T}{ }^{\prime}-R_{T} \\
& T=R_{T}{ }^{\prime}=R_{T}+\delta R
\end{aligned}
$$

Table 10.3 shows the comparison between the thrust, frictional resistance and friction coefficient with ITTC formulae. We see from the table that $k-\varepsilon$ Turbulence model gives better results than $\mathrm{k}-\omega$ turbulence model for this flow. The thrust deduction is found to be $=298.055-245.036=53.019 \mathrm{kN}$. So in the presence of the propeller, there is an increase of resistance of about $53 \mathrm{kN}$ for he ship under consideration.

This thrust deduction or increase in resistance due propeller rotation behind the hull.

Thrust deduction faction $t=\delta T / T$

$=53.019 / 298.055$

$=0.177$

Fig. 9 shows the static pressure distribution around propeller. It shows high pressure at face and low pressure at immediate back of propeller. But at the face of propeller blade near leading edge high pressure is created, this signifies the stagnation pressure striking the back surface of blade which leads to direction of drag force and lift force. The figure shows the stagnation pressure deviating the thrust force direction. 
Table 11: Computational estimation of resistance of ship thrust of

\begin{tabular}{|c|c|c|c|c|c|c|c|c|c|}
\hline \multicolumn{9}{|c|}{ pioperier. } & \multirow{5}{*}{$\begin{array}{l}\text { Thr } \\
\text { ust } \\
\mathrm{kN}\end{array}$} \\
\hline & & & \multirow{2}{*}{\multicolumn{2}{|c|}{\begin{tabular}{l|} 
ITTC \\
literature
\end{tabular}}} & \multicolumn{4}{|c|}{$\begin{array}{l}\text { Fluent estimation } \\
\text { Mesh size } 5472394\end{array}$} & \\
\hline & & & & & & \multicolumn{2}{|c|}{$\mathrm{k}-$} & \\
\hline \multicolumn{2}{|c|}{ Speed V } & & \multirow{2}{*}{$\begin{array}{l}C_{f s} \\
* 10 \\
3\end{array}$} & \multirow{2}{*}{$\begin{array}{l}\text { Fricti } \\
\text { onal } \\
\text { resist } \\
\text { ance }\end{array}$} & \multirow{2}{*}{$\begin{array}{c}C_{f s} \\
* 1 \\
0^{3}\end{array}$} & \multirow{2}{*}{$\begin{array}{l}\text { Visc } \\
\text { ous } \\
\text { resis } \\
\text { tanc }\end{array}$} & \multirow{2}{*}{$\begin{array}{c}C_{f s} \\
* 1 \\
0 \\
3\end{array}$} & \multirow{2}{*}{$\begin{array}{l}\text { Visc } \\
\text { ous } \\
\text { resis } \\
\operatorname{tanc}\end{array}$} & \\
\hline $\begin{array}{l}\text { (kn } \\
\text { ots) }\end{array}$ & $\mathrm{m} / \mathrm{s}$ & $\begin{array}{l}\mathrm{Rp} \\
\mathrm{m}\end{array}$ & & & & & & & \\
\hline 35 & 18 & 233 & 1.37 & 228.0 & 1.41 & 272. & 1.4 & 245. & 298 \\
\hline 35 & 18 & 180 & 1.37 & 228.0 & ----- & ------ & 1.3 & 244. & 30 \\
\hline
\end{tabular}

Fig.9: Pressure distribution over the propeller at 233rpm.

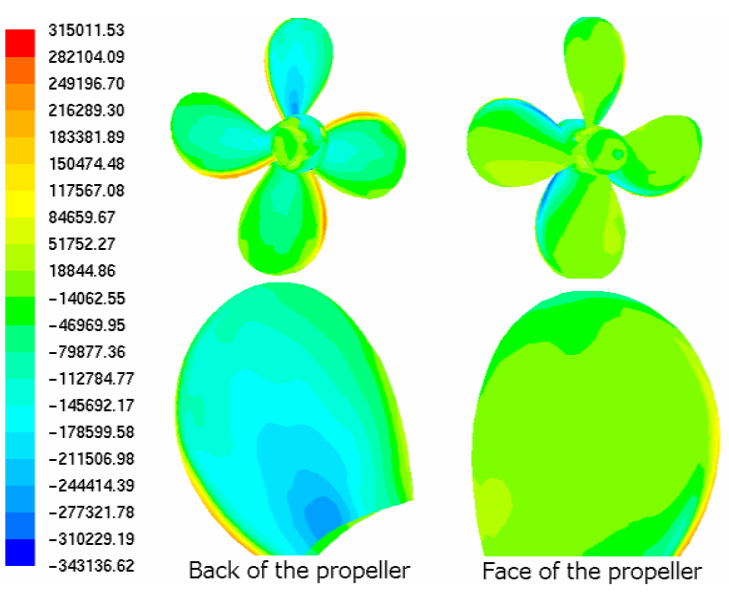

Fig . 10 shows the velocity vectors of propeller blade at different sections and at different Rpm of propeller. At those two Rpm of propeller flow separation is not developed. This flow separation leads to lift force and drag force of the propeller. If there is no flow separation then may not develop the drag force. Fig 11 shows linear $\mathrm{X}$ velocity and Fig. 12 shows velocity magnitude, i.e., resultant of $\mathrm{X}$ velocity and rotational velocity and radial velocity. Out of these three components, the rotational component is the maximum.

Fig. 11 Linear X-Velocity distribution around the

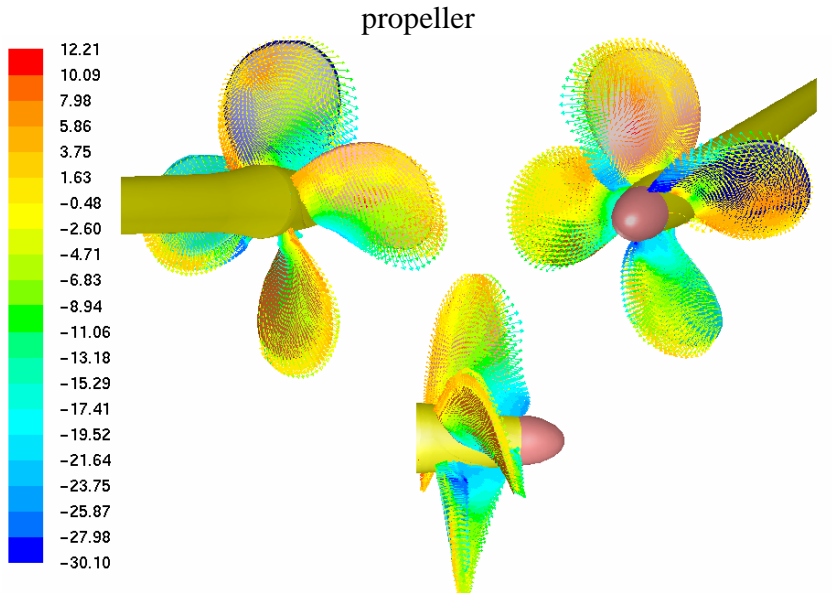

Fig. 10 Velocity vectors at different section of a blade
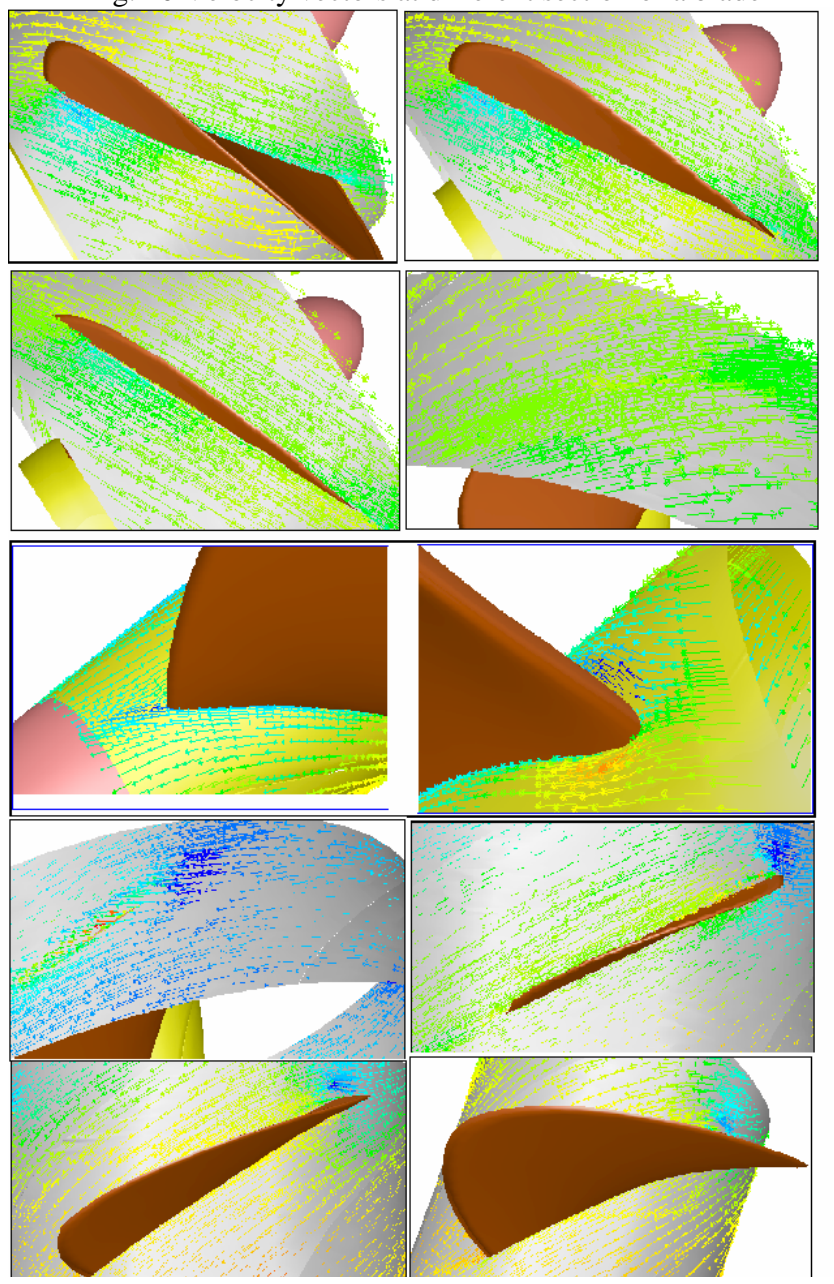

Fig. 12 velocity magnitude around the propeller

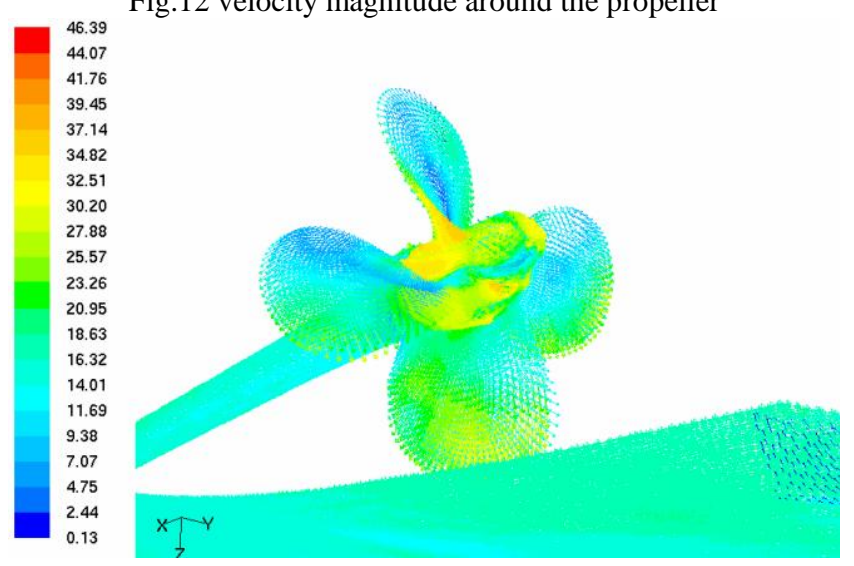




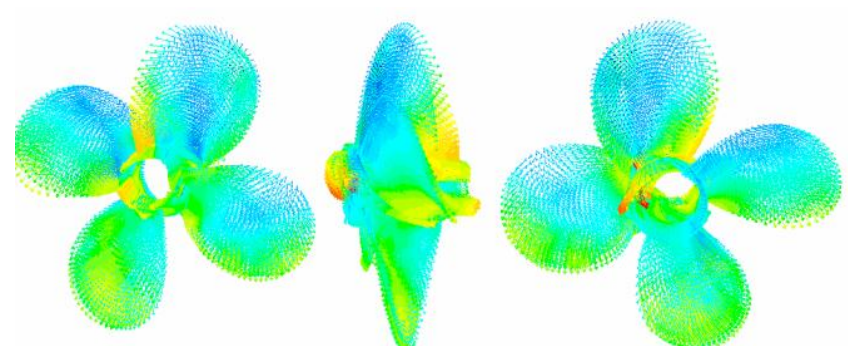

5. CONCLUSIONS

A high speed displacement ship (HSDS) of length $142 \mathrm{~m}$ and breadth $15 \mathrm{~m}$ was considered for CFD analysis for the purpose of determining the frictional resistance at $4.3 \mathrm{~m}$ draft. The open water characteristics, frictional resistance of bare hull, and frictional resistance and thrust with the propeller appended at the aft.

For the open water characteristics, a 4-bladed INSEAN E 779A model propeller is used for the computations. The diameter of the propeller is $227.2664 \mathrm{~mm}$, rotational speed varied from $1500 \mathrm{rpm}$ to $3000 \mathrm{rpm}$. The velocity of advance is $6.22 \mathrm{~m} / \mathrm{s}$. As the speed of rotation varied from 1500 to $3000 \mathrm{rpm}$, the thrust varied from $58 \mathrm{kN}$ to $2102 \mathrm{kN}$. The torque varied from $8 \mathrm{~N}-\mathrm{m}$ to around $90 \mathrm{~N}-\mathrm{m}$. The thrust coefficient varied from around 0.04 to about 0.38 while the torque coefficient given by $10 \mathrm{~K}_{\mathrm{q}}$ varied from 0.15 to 0.58 . The computed values of Torque coefficient and the thrust coefficient mentioned above match very accurately with the experimental results. This shows that the present CFD model is acceptable and the other components of interest can be determined.

Pressure distribution on the surface of blades while performing the open water characteristics shows high pressure at the face of the propeller and low pressure at the reverse of the blade. This explains the development of thrust by propeller at high pressures whereas the propeller is contributing to resistance. Also evident is a concentration of high-pressure region near the leading edge of the propeller.

The frictional resistance to a bare hull of the ship is computed for speeds varying from 9.72 to 35 knots equivalent to $5 \mathrm{~m} / \mathrm{s}$ to $18 \mathrm{~m} / \mathrm{s}$ respectively. The mesh size was varied from 146172 to 896412 hexahedral cells for each speed. Frictional resistance calculated for each speed. The value of frictional resistance did not differ substantially between the mesh sizes. This shows the grid independence of the model. The value of frictional resistance varied from $22 \mathrm{kN}$ to about $240 \mathrm{kN}$ as the speed increases. This is due to the higher velocity gradients at high speeds which contribute to the frictional resistance. The values determined by the CFD computations also matched reasonably well with ITTC empirical formula.

The next computation performed was the calculation of resistance with the propeller appended at the back of the hull. The speed selected for these computations is $35 \mathrm{~m} / \mathrm{s}$ since the ship is designed to run at that speed. The propeller was allowed to run at two speeds namely $233 \mathrm{rpm}$ (slow) and $1800 \mathrm{rpm}$ (fast). The k- $\varepsilon$ and k- $\omega$ models were used in Fluent for the estimation of the viscous resistance. It is found that $\mathrm{k}-\omega$ model gives a very high value of frictional resistance at 233 knots compared to the ITTC formula. The k- $\varepsilon$ model gives a value of $245 \mathrm{kN}$ frictional resistance at 233 knots compared to $228 \mathrm{kN}$ given by ITTC formula Thus we can say that the k- $\varepsilon$ model gives a reasonably accurate and acceptable prediction for the frictional resistance at 233 knots. So for further calculations, only the k- $\varepsilon$ model was only used. At $1800 \mathrm{rpm}$, the k- $\varepsilon$. model gives a resistance of 245 $\mathrm{kN}$ (which as expected does not vary with rotational speed of the propeller). The near coincidence of the values at $233 \mathrm{rpm}$ and $1800 \mathrm{rpm}$ shows that when the propeller is attached to the bare hull, the frictional resistance does not vary appreciably. The thrust generated by the propeller at $1800 \mathrm{rpm}$ is $306 \mathrm{kN}$ when it is appended at the aft of the ship, compared to $346 \mathrm{kN}$ in open water. This shows an appreciable reduction in the thrust generated by the propeller when it is attached to the bare hull. Even under this circumstances, the thrust generated by the hull is larger than the frictional resistance by about $50 \mathrm{kN}$. Thus the design of the propeller is acceptable for the high speed displacement ship under consideration. The other components of resistance namely Eddy resistance, air resistance, and appendage resistance were not considered in this thesis and their contribution to the total resistance needs to be taken into account when suggesting a suitable propeller for the ship under consideration. Determination of these resistances can be considered as scope for further work.

\section{ACKNOWLEDGMENTS}

We express our profound sense of gratitude to Dr. $\mathbf{V}$ Bhujanga Rao, Distinguished scientist, Director of Naval Science and Technological Laboratory (N.S.T.L), Visakhapatnam for giving permission to undertake this project work in Hydrodynamic Research Wing, N.S.T.L.

We wish to express our sincere thanks to Prof.I.Niranjan Kumar, Head of the Department Marine Engineering For his guidance and permitting to do the work in NSTL.

\section{REFERENCES}

[1] Armstrong, N.A (2000), On The Viscous Resistance And Form Factor Of High-Speed Catamaran-Ferry Hull Forms, Ph.D Thesis, The University Of New South Wales, Sydney, Australia.

[2] Insel, M. And Molland, A.F. (1992), An Investigation Into Resistance Components Of High-Speed Displacement Catamarans, Trans. Of Royal Institute Of Naval Architects, Vol.134, Pp 1-20

[3] Molland, A.F., Wellicome, J.F. And Couser, P.R. (1994), Resistance Experiments On A Systematic Series Of High Speed Displacement Catamaran Forms: Variation Of Length-Displacement Ratio And BreadthDraft Ratio, Ship Science Report No.71, University Of Southampton, UK.

[4] Schwetz, A, Sahoo, P K. (2002), Wave Resistance Of Semi-Displacement High Speed Catamarans Through CFD And Regression Analysis, Proc. 3rd International Euro Conference On High Performance Marine Vehicles (Hiper'02), Bergen, Norway, Pp 355-368.

[5] The Insean E779a Propeller Dataset, Model Geometry Description, Insean, Italian Ship Model Basin, Propulsion And Cavitation Laboratory. 
[6] Karl Randle And Peter Bull, "Predictions Of The Thrust And Torque Performance For Two Propeller Blades Using Computational Fluid Dynamics" International Conference On Marine CFD, March 2005 .

[7] Bong Jun Chang. "Application Of CFD To P4119 Propeller" $22^{\text {nd }}$ ITTC Propeller RANS/Panel Method Workshop, France, 1998

[8] Antonio Sanchez-Caja. “ P4119 RANS Calculations At VTTR" $22^{\text {nd }}$ ITTC Propeller RANS/Panel Method Workshop, France, 1998.

[9] J1. Reboud, "Numerical Simulation Of Unsteady Cavitating Flows: Some Applications And Open Problems", Legi, Grenoble, France, Fifth International Symposium On Cavitation, 2003.

[10] Unsteady Cavitating Turbulent Flow Simulation In A Kaplan Turbine, Shuhong Liu, Qingguang Chen, Department Of Thermal Engineering, Tsinghua University, Beijing, China, $2^{\text {nd }}$ Iahr International Meeting, Timisoara, Romania, 2007.
[11] Numerical Simulation Of Turbulent Flows With Sheet Cavitation, Inanc Senocak And Wei Shyy, Department Of Aerospace Engineering, Mechanics And Engineering Science, University Of Florida, Florida, 2001.

[12] An Introduction To Computational Fluid Dynamics, The Finite Volume Method, By H K Versteeg And W Malalasekhara, 1995.

[13] Turbulence Modeling For CFD, Second Edition By David C. Wilcox

[14] Fluid Dynamics Theoretical And Computational Approaches. Second Edition By Z.U.A. Warsi

[15] Fluent 6.2 Documentation, Users Guide.

[16] Basic Ship Propulsion, J.P. Ghosh, R.P. Gokaran, 2004.

[17] Principles Of Naval Architecture, Volume Ii, Edward V.Lewis. 